\title{
Financial Health Soundness Measurement of Private Commercial Banks in Bangladesh: An Observation of Selected Banks
}

\author{
Prof. Dr. Mohammad Main Uddin \\ Md. Abdul Kaium Masud
}

\begin{abstract}
The financial sector is one of the most significant sectors for any country, especially if a country is a developing in nature. In such an environment, banking sector plays the vital role to strengthen the economic conditions. Economic growth and international business is increasing in Bangladesh and private commercial banks especially private sectors play the major roles. Thus it becomes important to measure the financial soundness of the private banks in order to judge their respective position. The study was conducted to measure the financial soundness of selected private commercial banks of Bangladesh for the period 2006-2010. In this paper, an attempt was made to analyze the financial soundness of selected banks using different statistical tools and financial indicators. The study reveals that different financial indicators showed upward trends during the period 2006 to 2010. The study also made a rank of the selected commercial banks based on financial indicators. It was found that a bank with higher deposits, loans \& advances, investments, branches, employees does not always mean that has better profitability performance. The study also recommends measures that could be adopted by banks to ensure soundness in their operation.
\end{abstract}

Key Words: Private commercial bank, financial soundness, efficiency

\section{Introduction}

A bank as a matter of fact, is just like a heart in the economic structure and the Capital provided by it is like blood in it. Banks are the backbone of the global economy, providing capital for innovation, infrastructure, job creation and overall prosperity. Banks also play an integral role in society, affecting not only spending by individual consumers, but also the growth of entire industries. Economic development of the economy is reflected through the soundness of the banking system (Gaur et al. 2012) and its sound application. Banking is now an essential part of any economic system. Modern trade and commerce would almost be impossible without the availability of suitable banking services. First, banking promotes savings. All manner of people, from the ordinary laborers and workers to the rich land owners and businessmen, can keep their money safely in banks and saving centers. Secondly, banking promotes investments. Banks easily invest the money they get in industry, agriculture and trade. They either invest it directly or advance loans to other investors. Thirdly, it is most through banks that foreign trade is carried on. Whether we export or import, it is through banks that money is transferred from one country to another (Chodhury \& Kasfia, 2009). A number of recent studies, however, indicate that the banking sector plays a more important role than it was believed earlier (World Bank, 1996). Financial soundness helps us to measure the results of a firm's policies and operations in 20 
monetary terms also these results are reflected in the firm's return on investment, return on assets, value added (Makkar \& Singh, (2012). It also helps us to evaluate how well a bank is using its resources to make a profit. Common examples of financial performance include operating income, earnings before interest and taxes, and net asset value. It is important to note that no one measure of financial soundness should be taken on its own. Rather, a thorough assessment of a company's performance should take into account many different measures. Financial performance is a subjective measure of how well a bank can use assets from its primary mode of business and generate revenues. This term is also used as a general measure of a firm's overall financial health over a given period of time, and can be used to compare similar firms across the same industry or to compare industries or sectors in aggregation.

The health and efficiency of the financial sector are crucial to economic growth of a country because the pace of economic growth, a balanced capital market, an efficient flow of fund between savers and investors cannot be preserved without a sound financial sector (Lalarukh \& Hossain, 2008). Financial sector of Bangladesh, like most poor countries, is dominated by the banking enterprises (Ahmed, 2005). As a result, the performance of the banking sector has a direct correlation with the entire financial sector and economy of our country. In every country, the banking sector is the most important mechanism for performing a lot of tasks related to deposit mobilization, credit evaluation and monitoring, providing access to a payments system and to a clearing house for transactions. It is the system by which a country's most profitable and efficient projects are systematically and continuously funded, and thus it is the mechanism, which ensures that resources are directed to the most productive sources of the future growth. The system not only transfers funds from savers to investors, it must be able to select projects which will yield the highest returns, accumulate sufficient quantities of capital to fund the range of investment projects across economic activities, account for price risks across assets, monitor performance, and enforce contracts (Hassan, 1993). Therefore, in a country like Bangladesh, characterized by low savings rate, a large nonmonetized sector, lack of institutions to tap rural savings, the paramount importance of banking is well recognized (Abdul, 1987). As banks play the most major roles in the economy, it is important to evaluate the financial soundness of banks.

\subsection{Review of Literatures}

Almazari (2012) has attempted to analyze the financial performance of seven selected Jordanian commercial banks and pointed out that there exists a positive correlation between financial performance and asset size, asset utilization and operational efficiency. Moreover, the study has anticipated to make contributions in the field of banking and academic field.Earlier study have analyzed the development and growth of Selected Private Commercial Banks of Bangladesh. They observed that all the selected private commercial banks are able to achieve a stable growth of branches, employees, deposits, loans and advances, net income, earnings per share during the period of 2002-2006. At last, they concluded that the prospect of private commercial banks in Bangladesh is very bright. (Chodhury \& Kasfia, 2009)

One of the study in Bangladesh observed performance of private and national commenrcial banks of Bangladesh for the period of 2002-2005 and they pointed out that in financial category, PCBs performed better than that of NCBs but NCBs are very much desirable 
from social point of view and it is very difficult to accomplish dual objectives of monetary profitability and social consideration for the NCBs at the same time (Farjana \& Hossain, 2008). Chowdhury and Islam (2007) stated that deposits and loan advances of Nationalized Commercial Banks (NCBs) are less sensitive to interest changes than those of Specialized Banks (SBs). So SBs should not make abrupt change in lending or deposit rates by following the NCBs. If NCBs change their lending or deposit rates, their deposits or loans and advances will be affected less than those of SBs. Moreover, deposits of NCBs have higher volume and higher volatility than those of SBs. On the other hand, loans advances of NCBs show a higher volume and higher volatility than those of SBs. However, SBs offer higher deposit rates and charge higher lending rates than NCBs. That is why the interest rate spread of SBs was higher than that of NCBs.

Shill and Haque (2007) stated that the traditional measure of profitability through stockholder's equity is quite different in banking industry from any other sector of business, where loan-to-deposit ratio works as a very good indicator of banks' profitability as it depicts the status of asset-liability management of banks. But banks' risk is not only associated with this asset liability management but also related to growth opportunity. Smooth growth ensures higher future returns to holders and there lies the profitability which means not only current profits but future returns as well. So, market size and market concentration index along with return to equity and loan-to-deposit ratio grab the attention of analyzing the banks' profitability.

Chen et all (2005) applies frontier analysis (X-efficiency) using DEA to examine the cost, technical and a locative efficiency of 43 Chinese banks over the period 1993 to 2000. In this paper the input used are interest expenses, non-interest expenses (which includes the price of labor), price of deposits (interest paid on deposits divided by deposits), and the price of capital (non-interest expenses are divided by fixed assets) Outputs used are loans, deposits and non-interest income. Results show that the large state-owned banks and smaller banks are more efficient than medium sized Chinese banks. In addition, technical efficiency consistently dominates the locative efficiency of Chinese banks.

Productivity and profitability performance of private commercial bank in Bangladesh: A case study of Pubali bank Limited reveals that the productivity and profitability measures showed upwards trends during 1983-2001 (Rafiqul and Farid, 2004). Chowdhury (2002) observed that the banking industry of Bangladesh is a mixed one comprising nationalized, private and foreign commercial banks. Many efforts have been made to explain the performance of these banks. Understanding the performance of banks requires knowledge about the profitability and the relationships between variables like market size, bank's risk and bank's market size with profitability. Indeed, the performance evaluation of commercial banks is especially important today because of the fierce competition. The banking industry is experiencing major transition for the last two decades. It is becoming imperative for banks to endure the pressure arising from both internal and external factors and prove to be profitable.

Siddique and Islam (2001) pointed out that the Commercial Banks, as a whole, are performing well and contributing to the economic development of the country. The average profitability of all Bangladeshi banks collectively was 0.09\% during 1980 to 1995 which means that a profit of TK 0.09 was earned by utilizing assets of TK 100. In every aspect of profit, banking sector contributes the national economy as well as to the individual organization. Despite overall growth of the banking sector being positive, the performances of different categories of banks were not equally attractive. 
Chodhury F. (2000) used some parameters for analyzing managerial effectiveness of BKB, such as deposit mobilization; loan \& advance sanctioned and recovered, profitability, productivity etc. She found unsatisfactory performance. She conducted that for the quality management it is required to train-up more official at different levels of management. Matiur (1994) on the study "Trend of Employees" Productivity in Commercial Banks in Bangladesh" reveals the productivity in private commercial Banks was much higher than in the Nationalized Commercial Banks. He observed that per employees' deposit, advance and expenditure had almost an increasing trend in both NCBs and PCBs, but per employee profit and investments showed zigzag trend during the study period.

In a research paper named "A Decade of private Commercial Banking in Bangladesh" concluded that the performance of private banks is satisfactory excepting the quality of leading. The study suggested an implication of financial sector reform measures in the banking sector; financial discipline would revive and bring a congenial atmosphere for the healthy growth of private banks (Raqib, 1993). Shakoor (1989) pointed out "Productivity of nationalized commercial banks in Bangladesh had an increasing trend during 197286 that declined a little during 1983 to 1985 although there was an improvement during 1986. The major factors determining the productivity of NCBs are continuous increase in operational expenses, current expenses, establishment expenses, non-current expenses etc. Virtually spread to working fund had also a greater impact on the return on investment of the Banks. The governing factors of the increasing productivity are that there was better deposit mobilization and increasing advances in various sectors of NCBs. There was better recovery because of the effective utilization of the borrowed funds. Private Banks in Bangladesh showed better productivity by way of increasing earning through working fund, deposit mobilization and advances during 1983-86"

In a paper entitled "A preliminary note on measurement of productivity in the commercial banks of Bangladesh" showed that the cost control measures and improvement in earnings are essential elements for increasing the level of productivity. To enhance the efficiency of the bank employees, they suggest certain degree of mechanization and computerization, manpower planning and performance budgeting. Proper management of assets and liabilities would help to reduce cost and add to banks productivity (Abedin, et. al., 1989).

\section{Problems and Objectives}

The examination of financial soundness in banking has important public policy implications in the context of Bangladesh. The main objective of the study is to measure the financial soundness of private commercial Banks of Bangladesh. Along with the specific objective, the report also finds out the factors behind success and failure of private commercial banks of Bangladesh because determinants of financial soundness is very useful for managers in improving organizational performance and it also help the policy-making bodies.

\section{Data and Methods}

In order to achieve the specific objectives of the study secondary sources of data have been used. These data have been collected mainly from the annual reports of Bank Asia, Prime Bank, Mercantile Bank, Dutch Bangla Bank and Brac Bank ltd. The study covered a period starting from 2006 to 2010. In addition, data was gathered from Books, papers, articles, Specialized International Journals, the World Wide Web (Internet), and relevant previous studies. This study uses a descriptive financial analysis to describe, measure, compare, 
and classify the financial situations of the selected commercial banks. In measuring the financial soundness of selected Banks, the output has been defined as gross income, deposit, loans and advances, of the Bank. On the other hand employees, branches and various expenditures have been treated as input. In this study some soundness indicators are analyzed to measure the financial soundness of various parties such as deposit per employee, loan and advances per employee, investment per employee, income per branches, return on Assets, return on Equity, total assets etc (Almazari 2012). The descriptive statistics have been applied here for the purpose of making the report informative and representative. The following framework (Lalarukh and Hossain 2008) was taken into consideration to observe the financial soundness of selected private commercial banks.

Table 1: Framework of soundness measurement

\begin{tabular}{|c|c|c|}
\hline S.N & Criteria & Formula \\
\hline 1 & Branch Expansion & No. of Branches growth \\
\hline 2 & Employment Generation & No. of Employees growth \\
\hline 3 & $\begin{array}{l}\text { Deposit turnover: } \\
\text { a) Deposit turnover-employees } \\
\text { b) Deposit turnover-branch }\end{array}$ & $\begin{array}{l}\text { Total deposit/ No. of } \\
\text { employees } \\
\text { Total deposit/ No. of branches }\end{array}$ \\
\hline 4 & $\begin{array}{l}\text { Investment turnover: } \\
\text { a) Investment turnover } \\
\text { employees } \\
\text { b) Investment turnover -branch }\end{array}$ & $\begin{array}{l}\text { Total investment/ No. of employees } \\
\text { Total investment/ No. of } \\
\text { branches }\end{array}$ \\
\hline 5 & $\begin{array}{l}\text { Loan \& Advances turnover: } \\
\text { a) Loan \& Advances turn } \\
\text { over-employees } \\
\text { b) Loan \& Advances turnover } \\
\text {-branch }\end{array}$ & $\begin{array}{l}\text { Total Loan \& Advances / No. of } \\
\text { employees } \\
\text { Total Loan \& Advances / No. of } \\
\text { branches }\end{array}$ \\
\hline 6 & $\begin{array}{l}\text { Income turnover } \\
\text { Income turnover-employees } \\
\text { Income t turnover-branch }\end{array}$ & $\begin{array}{l}\text { Total Income / No. of } \\
\text { employees } \\
\text { Total Income /No. of branches }\end{array}$ \\
\hline
\end{tabular}


Financial Health Soundness Measurement of Private Commercial Banks ...

\begin{tabular}{|l|l|l|}
\hline 7 & Return on Assets & Net Income/Average Assets \\
\hline 8 & Return on Equity & Net Income/Average Equity \\
\hline
\end{tabular}

\section{Discussion and Analysis}

\subsection{Growth of Branches of Selected Banks}

Table: 1 shows the growth pattern of number of branches of selected banks for the year 2006 to 2010. The growth of branches is highest Bank Asia 29.82\% in comparing with 2009. However, DBBL has highest number of branches in the year 2010 (96). The lower growth percentage is Brack Bank 11.26\%. The average highest growth rate is Brack Bank $35.8 \%$ but average highest number of branches is prime bank 71.8. To rank the banks based on their average growth rate, Brack bank is considered to be number one, Dutch Bangla Bank is number two, and Bank Asia number three, Prime Bank and Mercantile Bank are four and five respectively as shown in table (1)

Table2: Number of branches of selected banks

\begin{tabular}{|l|l|c|c|c|c|c|c|}
\hline S. N & \multicolumn{1}{|c|}{ Name of Banks } & \multicolumn{6}{c|}{ Number of Branches } \\
\hline & Year & 2006 & 2007 & 2008 & 2009 & 2010 & Average \\
\hline 1 & Bank Asia Ltd. & 24 & 29 & 33 & 41 & 52 & 35.8 \\
\hline & Growth (\%) & & 20.83 & 13.79 & 24.24 & 26.82 & 21.4 \\
\hline 2 & Dutch Bangla Bank Ltd. & 39 & 49 & 64 & 79 & 96 & 65.4 \\
\hline & Growth (\%) & & 25.64 & 30.61 & 23.44 & 21.52 & 25.3 \\
\hline 3 & Mercantile Bank Ltd. & 35 & 41 & 42 & 53 & 65 & 47.2 \\
\hline & Growth (\%) & & 17.14 & 2.44 & 26.19 & 22.64 & 17.1 \\
\hline 4 & Prime Bank Ltd. & 50 & 61 & 70 & 84 & 94 & 71.8 \\
\hline & Growth (\%) & & 22 & 14.75 & 20 & 11.91 & 17.2 \\
\hline 5 & Brac Bank Ltd. & 23 & 36 & 56 & 71 & 79 & 53.0 \\
\hline & Growth (\%) & & 56.52 & 55.56 & 26.79 & 11.26 & 35.8 \\
\hline
\end{tabular}

\subsection{Growth of Employees of Five Banks}

Table: 2 Shows the growth pattern of employees of selected banks for the year 2006 to 2010. The growth of employees is highest Dutch Bangla Bank 54.79\% in comparing with 2009. Moreover, Brack Bank has highest number of employees in the year 2010 (7151). The lower growth percentage is Prime Bank 16\% in comparing with 2009. The average highest growth rate is Dutch Bangla Bank 42.8\% but average highest employees is Brack Bank 4945 in 2010. To rank the banks based on their average growth rate, Dutch Bangla Bank is considered to be number one, Brack Bank is number two, and Bank Asia number three, Mercantile Bank and Prime Bank are four and five respectively as shown in table (2). 
Table 3: Employees of selected banks

\begin{tabular}{|c|l|c|c|c|c|c|c|}
\hline SN & \multicolumn{1}{|c|}{ Name of Banks } & & \multicolumn{5}{c|}{ Number of Employees } \\
\hline & \multicolumn{1}{|c|}{ Year } & 2006 & 2007 & 2008 & 2009 & 2010 & Average \\
\hline 1 & Bank Asia Ltd. & 515 & 639 & 802 & 1031 & 1237 & 844.8 \\
\hline & Growth & & 24.08 & 25.51 & 28.55 & 19.98 & 24.5 \\
\hline 2 & Dutch Bangla Bank Ltd. & 684 & 789 & 1229 & 1785 & 2763 & 1450.0 \\
\hline & Growth & & 15.35 & 55.77 & 45.24 & 54.79 & 42.8 \\
\hline 3 & Mercantile Bank Ltd. & 879 & 945 & 1115 & 1303 & 1605 & 1169.4 \\
\hline & Growth & & 7.51 & 17.99 & 16.86 & 23.18 & 16.4 \\
\hline 4 & Prime Bank Ltd. & 1172 & 1400 & 1551 & 1844 & 2139 & 1621.2 \\
\hline & Growth & & 19.45 & 10.78 & 18.89 & 16.00 & 16.3 \\
\hline 5 & Brac Bank Ltd. & 3047 & 4428 & 4192 & 5907 & 7151 & 4945.0 \\
\hline & Growth & & 45.32 & -5.33 & 40.91 & 21.06 & 25.5 \\
\hline
\end{tabular}

\subsection{Growth of Deposit of Selected Banks}

Table (3) shows total deposits for all the selected Private commercial banks of Bangladesh through years 2006-2010, and provides the growth rate of deposits. The average of total deposits for Bank Asia is 47,232.6 Million Taka with growth rate 52.47\% in year 2010 comparing with year 2009. On the other hand, average growth of deposit per employee and deposit per branch of Bank Asia is 9\% and 11.7\% respectively. Table 2 indicates highest average deposited Bank is Prime Bank 88,946.4 million Taka, average highest deposit growth rate Bank is Brack Bank $41.19 \%$, average highest growth rate of deposit per employees bank is Brack Bank is 16.2\% and average highest growth rate of deposit per branch bank is Bank Asia 11.7\%. Dutch Bangla Bank is very poor position in growth rate of deposit per employee and deposit per branch $-14.8 \%$ and $-3.8 \%$ respectively. The table results that as much as Banks are increased Branches and Employees but failed to collect deposit.

To rank the banks based on their average deposit turnover, Brack Bank is considered to be number one, Bank Asia is number two, Mercantile Bank and Prime Bank are four and Dutch Bangla Bank five is number four as shown in table (3).

\subsection{Loans and Advances Turnover and Growth of Selected Banks:}

Table (4) results total loans and advances for all the selected Private commercial banks of Bangladesh through years 2006-2010, and provide the growth rate of loans and advances along with growth rate of loan and advances per employees and branches. It is clear from the table that Prime bank is the highest average of total loan and advances 75,653.6 Million Taka, and Mercantile bank is the lowest one 43,362.5 million Taka. Average highest growth rate is Brack Bank 48.3\% and lowest one is Dutch Bangla Bank 23.6\%. On the other hand, 
Financial Health Soundness Measurement of Private Commercial Banks ...

Table 4: Deposit Turnover and Growth

\begin{tabular}{|c|c|c|c|c|c|c|c|}
\hline \multirow[t]{2}{*}{ S.L } & \multicolumn{2}{|l|}{ Name of Banks } & \multicolumn{5}{|c|}{ Total Deposits } \\
\hline & Year & 2006 & 2007 & 2008 & 2009 & 2010 & Average \\
\hline \multirow[t]{6}{*}{1} & Bank Asia Ltd. & $25,289.36$ & $30,004.09$ & $42,435.24$ & $54,832.82$ & $83,601.26$ & $47,232.6$ \\
\hline & Growth (\%) & & 18.64 & 41.43 & 29.22 & 52.47 & 35.4 \\
\hline & Deposit per employee & 49.11 & 46.95 & 52.91 & 53.18 & 67.58 & 53.9 \\
\hline & Growth & & -4.39 & 12.69 & 0.51 & 27.08 & 9.0 \\
\hline & Deposit p & 1053.72 & 1034.62 & 1285.92 & 1337.39 & 1607.72 & $1,263.9$ \\
\hline & Growth & & -1.81 & 24.29 & 4.00 & 20.21 & 11.7 \\
\hline \multirow[t]{6}{*}{2} & Dutch Ban & 40111.54 & 42110.15 & 51575.67 & 67788.53 & 83244.77 & $56,966.1$ \\
\hline & Growth (\%) & & 4.98 & 22.48 & 31.44 & 22.80 & 20.4 \\
\hline & Deposit per $\epsilon$ & 58.64 & 57.37 & 41.97 & 37.98 & 30.13 & 45.2 \\
\hline & Growth (\%) & & -2.17 & -26.84 & -9.50 & -20.67 & -14.8 \\
\hline & Deposit per branch & 1028.50 & 859.39 & 805.87 & 858.08 & 867.13 & 883.8 \\
\hline & Growth (\%) & & -16.44 & -6.23 & 6.47 & 1.05 & -3.8 \\
\hline \multirow[t]{6}{*}{3} & Mercantile Bank Ltd. & 33332.65 & 39348.0 & 49538.35 & $58,033.47$ & $75,629.14$ & $51,176.3$ \\
\hline & Growth (\%) & & 18.05 & 25.90 & 17.15 & 30.32 & 22.9 \\
\hline & Deposit per employee & 37.92 & 41.64 & 44.43 & 44.54 & 47.12 & 43.1 \\
\hline & Growth (\%) & & 9.81 & 6.70 & 0.25 & 5.79 & 5.6 \\
\hline & Deposit per branch & 952.36 & 959.71 & 1179.48 & 1094.97 & 1163.53 & $1,070.0$ \\
\hline & Growth (\%) & & 0.77 & 22.90 & -7.17 & 6.26 & 5.7 \\
\hline \multirow[t]{6}{*}{4} & Prime Bank Ltd. & 54724 & 70512 & 88021 & 106956 & 124519 & $88,946.4$ \\
\hline & Growth (\%) & & 28.85 & 24.83 & 21.51 & 16.42 & 22.9 \\
\hline & Deposit per employee & 46.69 & 50.37 & 56.75 & 58.00 & 58.21 & 54.0 \\
\hline & Growth (\%) & & 7.88 & 12.67 & 2.20 & 0.36 & 5.8 \\
\hline & Deposit per branch & 1094.48 & 1155.93 & 1257.44 & 1273.29 & 1324.67 & $1,221.2$ \\
\hline & Growth (\%) & & 5.61 & 8.78 & 1.26 & 4.03 & 4.9 \\
\hline \multirow[t]{6}{*}{5} & Brac Bank Ltd. & 23002 & 37368 & 58007 & 75220 & 88158 & $56,351.0$ \\
\hline & Growth (\%) & & 62.46 & 55.23 & 29.67 & 17.203 & 41.1 \\
\hline & Deposit per employee & 7.55 & 8.44 & 13.84 & 12.73 & 12.33 & 11.0 \\
\hline & Growth (\%) & & 11.79 & 63.97 & -7.97 & -3.19 & 16.2 \\
\hline & Deposit per branch & 1000.08 & 1038 & 1035.84 & 1059.44 & $1115 . .92$ & $1,033.3$ \\
\hline & Growth (\%) & & 3.79 & -.21 & 2.28 & 5.33 & 2.8 \\
\hline
\end{tabular}




\subsection{Loans and Advances Turnover and Growth of Selected Banks}

Table (4) results total loans and advances for all the selected Private commercial banks of Bangladesh through years 2006-2010, and provide the growth rate of loans and advances along with growth rate of loan and advances per employees and branches. It is clear from the table that Prime bank is the highest average of total loan and advances 75,653.6 Million Taka, and Mercantile bank is the lowest one 43,362.5 million Taka. Average highest growth rate is Brack Bank 48.3\% and lowest one is Dutch Bangla Bank 23.6\%. On the other hand, highest average growth of loan and advances per employees and branch is Brack Bank 26.9\% and Bank Asia 13.8\% respectively and lowest one is Dutch Bangla Bank -13.8\% and $-1.4 \%$ respectively. The table find out that banks are in good position for providing loan and advances in relation with deposit collection.

To rank the banks based on their average loan and advances turnover, Prime Bank is considered to be number one, Bank Asia is number two and Brack bank is number three, Dutch Bangla Bank and Mercantile Bank are number four and five respectively.

Table 5: Total loans and advances turnover and growth (Million in Taka)

\begin{tabular}{|l|l|c|c|c|c|c|c|}
\hline SL & Name of Banks & \multicolumn{5}{|c|}{ Total Loans \& Advances } & \\
\hline & Year & 2006 & 2007 & 2008 & 2009 & 2010 & Average \\
\hline 1 & Bank Asia Ltd. & $22,255.64$ & $28,456.94$ & $39,975.00$ & $50,267.92$ & $79,504.23$ & $44,091.9$ \\
\hline & Growth (\%) & & 27.83 & 40.48 & 25.75 & 58.16 & 38.1 \\
\hline \multirow{7}{*}{$\begin{array}{l}\text { L \& A per } \\
\text { employee }\end{array}$} & 43.21 & 44.53 & 49.84 & 48.76 & 64.27 & 50.1 \\
\cline { 2 - 8 } & Growth (\%) & & 3.05 & 11.92 & -2.17 & 31.81 & 11.2 \\
\hline & L \& A per branch & 927.32 & 981.27 & 1211.36 & 1226.05 & 1528.93 & $1,175.0$ \\
\cline { 2 - 8 } & Growth (\%) & & 5.82 & 23.45 & 1.21 & 24.73 & 13.8 \\
\hline \multirow{2}{*}{2} & $\begin{array}{l}\text { Dutch Bangla } \\
\text { Bank Ltd. }\end{array}$ & 30456.32 & 29403.12 & 41698.32 & 48410.99 & 67657.67 & $43,525.3$ \\
\hline \multirow{2}{*}{ Growth (\%) } & & -3.46 & 41.82 & 16.10 & 39.76 & 23.6 \\
\hline \multirow{2}{*}{$\begin{array}{l}\text { L \& A per } \\
\text { employee }\end{array}$} & 44.53 & 37.27 & 33.93 & 27.12 & 24.49 & 33.5 \\
\cline { 2 - 8 } & Growth (\%) & & -16.31 & -8.96 & -20.07 & -9.70 & -13.8 \\
\cline { 2 - 8 } & L \& A per branch & 780.93 & 600.01 & 651.54 & 612.78 & 704.76 & 670.0 \\
\cline { 2 - 8 } & Growth (\%) & & -23.17 & 8.59 & -5.95 & 15.01 & -1.4 \\
\hline \multirow{2}{*}{3} & $\begin{array}{l}\text { Mercantile Bank } \\
\text { Ltd. }\end{array}$ & 26842.14 & 31877.86 & 43419.36 & $48,295.55$ & $66,377.70$ & $43,362.5$ \\
\hline & Growth (\%) & 18.76 & 36.21 & 11.23 & 37.44 & 25.9 \\
\hline
\end{tabular}

Contd... 
Financial Health Soundness Measurement of Private Commercial Banks ...

\begin{tabular}{|l|l|c|c|c|c|c|c|}
\hline \multirow{2}{*}{$\begin{array}{l}\text { L \& A per } \\
\text { employee }\end{array}$} & 30.54 & 33.73 & 38.94 & 37.06 & 41.36 & 36.3 \\
\cline { 2 - 7 } & Growth (\%) & & 10.45 & 15.45 & -4.83 & 11.60 & 8.2 \\
\cline { 2 - 8 } & L \& A per branch & 766.92 & 777.51 & 1033.79 & 911.24 & 1021.12 & 902.1 \\
\cline { 2 - 8 } & Growth (\%) & & 1.38 & 32.96 & -11.85 & 12.06 & 8.6 \\
\hline \multirow{2}{*}{4} & Prime Bank Ltd. & 45010 & 57683 & 75156 & 89252 & 111167 & $75,653.6$ \\
\hline \multirow{3}{*}{} & Growth (\%) & & 28.16 & 30.29 & 18.76 & 24.55 & 25.4 \\
\hline \multirow{2}{*}{$\begin{array}{l}\text { L \& A per em- } \\
\text { ployee }\end{array}$} & 38.40 & 41.20 & 48.46 & 48.40 & 51.97 & 45.7 \\
\cline { 2 - 8 } & Growth (\%) & & 7.29 & 17.62 & -0.12 & 7.38 & 8.0 \\
\cline { 2 - 8 } & L \& A per branch & 900.20 & 945.62 & 1073.66 & 1062.52 & 1182.63 & $1,032.9$ \\
\cline { 2 - 8 } & Growth (\%) & & 5.05 & 13.54 & -1.04 & 11.30 & 7.2 \\
\hline \multirow{2}{*}{5} & Brac Bank Ltd. & 19557 & 24610 & 52677 & 64151 & 84303 & 49059.6 \\
\hline \multirow{2}{*}{} & & 25.84 & 114.08 & 21.78 & 31.41 & 48.3 \\
\hline \multirow{2}{*}{ Growth (\%) } & $\begin{array}{l}\text { L \& A per } \\
\text { employee }\end{array}$ & 6.42 & 5.56 & 12.57 & 10.86 & 11.79 & 9.4 \\
\cline { 2 - 8 } & Growth (\%) & -13.40 & 126.08 & -13.58 & 8.55 & 26.9 \\
\cline { 2 - 8 } & L \& A per branch & 850.30 & 683.36 & 940.66 & 903.54 & 1067.13 & 889.0 \\
\cline { 2 - 8 } & Growth (\%) & & -19.63 & 37.65 & -3.95 & 18.11 & 8.0 \\
\hline
\end{tabular}

\subsection{Growth of Net Income of Selected Banks}

Table (5) results net income turnover and growth of all the selected Private commercial banks of Bangladesh through years 2006-2010, along with growth rate of income per branch and employees. It is clear from the table that Prime bank is the highest average of net income 1894.4 Million Taka, and Mercantile bank is the lowest one 776.7 million Taka. Average highest growth rate is Dutch Bangla Bank 54.5\% and lowest one is Mercantile Bank 32.7\%. On the other hand, highest average income per branch and employees is Bank Asia 27\% and 1.2\% respectively and lowest one is Dutch Bangla Bank 13.4\% and Brack Bank 0.2\%. The table fined out that comparatively banks net income isn't in a stable position.

To rank the banks based on their average net income turnover, Prime Bank is considered to be number one, Bank Asia is number two and Brack bank is number three, Dutch Bangla Bank and Mercantile Bank are number four and five respectively.

\subsection{Growth of Investment of Selected Banks}

Table (6) results investment turnover and growth of all the selected Private commercial banks of Bangladesh through years 2006-2010, along with growth rate of investment per branch and employees. It can be noted from the table that Mercantile bank is the highest 
average of investment 39,075.7 Million Taka, and Bank Asia is the lowest one 7084.2 million Taka. Average highest growth rate is Mercantile Bank 143.6\% and lowest one is Dutch Bangla Bank 21.6\%. On the other hand, highest average investment per branch and employees is Mercantile Bank 779.7\% and 31.4\% respectively and lowest one is Dutch Bangla Bank 118.3\% and Brack Bank 1.6\%. The table finds out that banks investment turnover is increasing year-by-year but not as much as increasing branches and employees.

Table 6: Net income turnover and growth

\begin{tabular}{|c|c|c|c|c|c|c|c|}
\hline \multirow[t]{2}{*}{ SN } & \multirow{2}{*}{$\frac{\text { Name of Banks }}{\text { Year }}$} & \multicolumn{5}{|c|}{ Net Income } & \multirow[b]{2}{*}{ Average } \\
\hline & & 2006 & 2007 & 2008 & 2009 & 2010 & \\
\hline \multirow[t]{6}{*}{1} & Bank Asia Ltd. & 475.76 & 725.64 & 686.70 & $1,327.18$ & $1,929.58$ & 1029.0 \\
\hline & Growth (\%) & & 52.52 & -5.37 & 93.27 & 45.39 & 46.5 \\
\hline & $\begin{array}{l}\text { Income per } \\
\text { Branch }\end{array}$ & 19.82 & 25.02 & 20.81 & 32.37 & 37.11 & 27.0 \\
\hline & Growth (\%) & & 26.24 & -16.83 & 55.55 & 14.64 & 19.9 \\
\hline & $\begin{array}{l}\text { Income per } \\
\text { employees }\end{array}$ & 0.92 & 1.14 & 0.86 & 1.29 & 1.56 & 1.2 \\
\hline & Growth (\%) & & 23.91 & -24.56 & 50.00 & 20.93 & 17.6 \\
\hline \multirow[t]{6}{*}{2} & $\begin{array}{l}\text { Dutch Bangla } \\
\text { Bank Ltd. }\end{array}$ & 362.18 & 479.81 & 821.67 & 1137.70 & 2002.32 & 960.7 \\
\hline & Growth (\%) & & 32.48 & 71.25 & 38.46 & 76.00 & 54.5 \\
\hline & $\begin{array}{l}\text { Income per } \\
\text { Branch }\end{array}$ & 9.28 & 9.79 & 12.84 & 14.40 & 20.86 & 13.4 \\
\hline & Growth (\%) & & 5.50 & 31.15 & 12.15 & 44.86 & 23.4 \\
\hline & $\begin{array}{l}\text { Income per } \\
\text { employees }\end{array}$ & 0.53 & 0.61 & 0.67 & 0.64 & 0.72 & 0.6 \\
\hline & Growth (\%) & & 15.09 & 9.84 & -4.48 & 12.50 & 8.2 \\
\hline \multirow[t]{6}{*}{3} & $\begin{array}{l}\text { Mercantile Bank } \\
\text { Ltd. }\end{array}$ & 494.22 & 540.50 & 615.88 & 807.52 & $1,425.34$ & 776.7 \\
\hline & Growth (\%) & & 9.36 & 13.95 & 31.12 & 76.51 & 32.7 \\
\hline & $\begin{array}{l}\text { Income per } \\
\text { Branch }\end{array}$ & 14.12 & 13.18 & 14.66 & 15.23 & 21.93 & 15.8 \\
\hline & Growth (\%) & & -6.66 & 11.23 & 3.89 & 43.99 & 13.1 \\
\hline & $\begin{array}{l}\text { Income per } \\
\text { employees }\end{array}$ & 0.56 & 0.57 & 0.55 & 0.62 & 0.89 & 0.6 \\
\hline & Growth (\%) & & 1.79 & -3.51 & 12.73 & 43.55 & 13.6 \\
\hline 4 & Prime Bank Ltd. & 1052 & 1401 & 1232 & 2784 & 3003 & 1894.4 \\
\hline
\end{tabular}

Contd... 
Financial Health Soundness Measurement of Private Commercial Banks ...

\begin{tabular}{|l|l|l|l|l|l|l|l|}
\hline & Growth (\%) & & 33.17 & -12.06 & 125.97 & 7.87 & 38.7 \\
\cline { 2 - 7 } & $\begin{array}{l}\text { Income per } \\
\text { Branch }\end{array}$ & 21.04 & 22.97 & 17.6 & 33.14 & 31.95 & 25.3 \\
\cline { 2 - 7 } & Growth (\%) & & 9.17 & -23.38 & 88.30 & -3.59 & 17.6 \\
\hline $\begin{array}{l}\text { Income per } \\
\text { employees }\end{array}$ & 0.89 & 1.00 & 0.79 & 1.51 & 1.40 & 1.1 \\
\cline { 2 - 8 } & Growth (\%) & & 12.36 & -21.00 & 91.14 & -7.28 & 18.8 \\
\hline 5 & Brac Bank Ltd. & 334 & 618 & 973 & 1304 & 1664 & 978.6 \\
\hline \multirow{2}{*}{} & Growth (\%) & & 85.03 & 57.44 & 34.02 & 27.61 & 51.0 \\
\hline $\begin{array}{l}\text { Income per } \\
\text { Branch }\end{array}$ & 14.52 & 17.17 & 17.38 & 18.37 & 21.06 & 17.7 \\
\cline { 2 - 8 } Growth (\%) & & 18.25 & 1.22 & 5.70 & 14.64 & 10.0 \\
\cline { 2 - 8 } & $\begin{array}{l}\text { Income per } \\
\text { employees }\end{array}$ & 0.11 & 0.14 & 0.23 & 0.22 & 0.23 & 0.2 \\
\hline & Growth (\%) & 27.32 & 66.31 & -4.89 & 5.41 & 23.5 \\
\hline
\end{tabular}

To rank the banks based on their average investment turnover, Mercantile Bank is considered to be number one, Prime Bank is number two and Brack bank is number three, Dutch Bangla Bank and Bank Asia are number four and five respectively.

Table 7: Investment turnover and growth

\begin{tabular}{|c|l|c|c|c|c|c|c|}
\hline SN & \multicolumn{1}{|c|}{ Name of Banks } & \multicolumn{5}{|c|}{ Total Investment } & \\
\hline & \multicolumn{1}{|c|}{ Year } & 2006 & 2007 & 2008 & 2009 & 2010 & Average \\
\hline 1 & Bank Asia Ltd. & $3,345.33$ & $4,203.14$ & $6,133.81$ & $9,663.10$ & $12,075.70$ & $7,084.2$ \\
\hline \multirow{2}{*}{} & Growth (\%) & & 25.64 & 45.93 & 57.54 & 24.97 & 38.5 \\
\cline { 2 - 8 } & $\begin{array}{l}\text { Investment per } \\
\text { branch }\end{array}$ & 139.39 & 144.94 & 185.87 & 235.69 & 232.23 & 187.6 \\
\cline { 2 - 8 } & Growth (\%) & & 3.98 & 28.24 & 26.80 & -1.47 & 14.4 \\
\cline { 2 - 8 } & $\begin{array}{l}\text { Investment per } \\
\text { employees }\end{array}$ & 6.50 & 6.58 & 7.65 & 9.37 & 9.76 & 8.0 \\
\cline { 2 - 8 } & Growth (\%) & & 1.23 & 16.26 & 22.48 & 4.16 & 11.0 \\
\hline \multirow{2}{*}{2} & $\begin{array}{l}\text { Dutch Bangla } \\
\text { Bank Ltd. }\end{array}$ & 5876.52 & 5909.32 & 5322.31 & 9685.88 & 11001.61 & $7,559.1$ \\
\hline \multirow{2}{*}{} & Growth (\%) & & 0.56 & -9.93 & 81.99 & 13.58 & 21.6 \\
\cline { 2 - 8 } & $\begin{array}{l}\text { Investment per } \\
\text { branch }\end{array}$ & 150.68 & 120.60 & 83.16 & 122.61 & 114.60 & 118.3 \\
\cline { 2 - 8 } & Growth (\%) & & -19.96 & -31.04 & 47.44 & -6.53 & -2.5 \\
\cline { 2 - 8 } & $\begin{array}{l}\text { Investment per } \\
\text { employees }\end{array}$ & 8.59 & 7.49 & 4.33 & 5.43 & 3.98 & 6.0 \\
\hline & Growth (\%) & -12.81 & -42.19 & 25.40 & -26.70 & -14.1 \\
\hline
\end{tabular}


The Journal of Nepalese Bussiness Studies

\begin{tabular}{|c|c|c|c|c|c|c|c|}
\hline 3 & $\begin{array}{l}\text { Mercantile Bank } \\
\text { Ltd. }\end{array}$ & 5407.90 & 31877.86 & 43419.36 & 48295.55 & 66377.70 & $39,075.7$ \\
\hline & Growth (\%) & & 489.47 & 36.21 & 11.23 & 37.44 & 143.6 \\
\hline & $\begin{array}{l}\text { Investment per } \\
\text { branch }\end{array}$ & 154.51 & 777.51 & 1033.79 & 911.24 & 1021.20 & 779.7 \\
\hline & Growth (\%) & & 403.21 & 32.96 & -11.85 & 12.07 & 109.1 \\
\hline & $\begin{array}{l}\text { Investment per } \\
\text { employees }\end{array}$ & 6.15 & 33.73 & 38.94 & 37.06 & 41.36 & 31.4 \\
\hline & Growth (\%) & & 448.46 & 15.45 & -4.83 & 11.60 & 117.7 \\
\hline \multirow[t]{6}{*}{4} & Prime Bank Ltd. & 7844 & 12698 & 23104 & 19934 & 20484 & $16,812.8$ \\
\hline & Growth (\%) & & 61.88 & 81.95 & -13.72 & 2.76 & 33.2 \\
\hline & $\begin{array}{l}\text { Investment per } \\
\text { branch }\end{array}$ & 156.88 & 208.16 & 330.06 & 237.31 & 217.91 & 230.1 \\
\hline & Growth (\%) & & 32.69 & 58.56 & -28.10 & -8.17 & 13.7 \\
\hline & $\begin{array}{l}\text { Investment per } \\
\text { employees }\end{array}$ & 6.69 & 9.07 & 14.90 & 10.81 & 9.58 & 10.2 \\
\hline & Growth (\%) & & 35.58 & 64.28 & -27.45 & -11.38 & 15.3 \\
\hline \multirow[t]{6}{*}{5} & Brack Bank Ltd. & 3768 & 4997 & 8245 & 10375 & 12856 & $8,048.2$ \\
\hline & Growth (\%) & & 32.62 & 65.00 & 25.83 & 23.91 & 36.8 \\
\hline & $\begin{array}{l}\text { Investment per } \\
\text { branch }\end{array}$ & 163.83 & 138.81 & 147.23 & 146.13 & 162.73 & 151.7 \\
\hline & Growth (\%) & & -15.27 & 6.07 & -0.75 & 11.36 & 0.4 \\
\hline & $\begin{array}{l}\text { Investment per } \\
\text { employees }\end{array}$ & 1.24 & 1.13 & 1.97 & 1.76 & 1.80 & 1.6 \\
\hline & Growth (\%) & & -8.74 & 74.29 & -10.70 & 2.36 & 14.3 \\
\hline
\end{tabular}

\section{7: Return on Assets of Selected Banks}

Return on assets indicates an overall profitability of Assets. Table (7) shows return on assets of all the selected Private commercial banks of Bangladesh through years 20062010. It is clear from the table that Bank Asia is the highest average return on assets 2.03 and Dutch Bangla Bank is the highest growth of return on assets $25.26 \%$ during the period. On the other hand, Brack Bank is the lowest growth of return on assets $2.25 \%$.

Table 8: Return on assets (ROA)

\begin{tabular}{|c|l|c|c|c|c|c|c|}
\hline \multirow{2}{*}{ SN } & \multicolumn{1}{|c|}{ Name of Banks } & \multicolumn{5}{|c|}{ Return on Assets } & \\
\hline & \multicolumn{1}{|c|}{ Year } & 2006 & 2007 & 2008 & 2009 & 2010 & Average \\
\hline 1 & Bank Asia Ltd. & 1.77 & 2.11 & 1.87 & 2.18 & 2.22 & 2.03 \\
\hline & Growth & & 19.21 & -11.37 & 16.58 & 1.83 & 6.56 \\
\hline
\end{tabular}

Contd... 
Financial Health Soundness Measurement of Private Commercial Banks ...

\begin{tabular}{|c|l|c|c|c|c|c|c|}
\hline 2 & Dutch Bangla Bank Ltd. & 0.93 & 1.01 & 1.49 & 1.60 & 2.20 & 1.45 \\
\hline & Growth & & 8.60 & 47.52 & 7.40 & 37.5 & 25.26 \\
\hline 3 & Mercantile Bank Ltd. & 1.33 & 1.20 & 1.10 & 1.22 & 1.64 & 1.30 \\
\hline & Growth & & -9.77 & -8.33 & 10.91 & 34.42 & 6.81 \\
\hline 4 & Prime Bank Ltd. & 2.05 & 1.99 & 1.30 & 2.37 & 2.16 & 1.97 \\
\hline & Growth & & -2.93 & -34.67 & 82.30 & -8.86 & 8.96 \\
\hline 5 & Brac Bank Ltd. & 1.43 & 1.62 & 1.64 & 1.56 & 1.55 & 1.56 \\
\hline & Growth & & 13.29 & 1.23 & -4.88 & -0.64 & 2.25 \\
\hline
\end{tabular}

\section{7: Return on Equity of Selected Banks}

Return on equity indicates an overall profitability of Equity. Table (8) shows return on equity of all the selected Private commercial banks of Bangladesh through years 20062010. It is clear from the table that Bank Asia is the highest average return on equity 29.17 and Dutch Bangla Bank is the highest growth of return on equity $10.50 \%$ during the period. On the other hand, Brack Bank is the lowest growth of return on equity $-4.81 \%$.

Table 9: Return on equity

\begin{tabular}{|c|l|c|c|c|c|c|c|}
\hline SL & \multicolumn{1}{|c|}{ Name of Banks } & \multicolumn{5}{|c|}{ Return on Equity } & \\
\hline & Year & 2006 & 2007 & 2008 & 2009 & 2010 & Average \\
\hline 1 & Bank Asia Ltd. & 27.06 & 31.63 & 23.00 & 32.03 & 32.12 & 29.17 \\
\hline & Growth & & 16.89 & -27.28 & 39.26 & 0.28 & 7.29 \\
\hline 2 & Dutch Bangla Bank Ltd. & 24.07 & 24.02 & 29.89 & 30.28 & 35.27 & 28.71 \\
\hline & Growth & & -0.21 & 24.44 & 1.30 & 16.48 & 10.50 \\
\hline 3 & Mercantile Bank Ltd. & 21.94 & 18.45 & 17.75 & 18.80 & 19.84 & 19.36 \\
\hline & Growth & & -15.91 & -3.79 & 5.92 & 5.53 & -2.06 \\
\hline 4 & Prime Bank Ltd. & 31.55 & 30.68 & 20.58 & 30.19 & 21.06 & 26.81 \\
\hline & Growth & & -2.76 & -32.92 & 46.70 & -30.24 & -4.81 \\
\hline 5 & Brac Bank Ltd. & 23.04 & 23.83 & 22.88 & 19.19 & 18.95 & 21.58 \\
\hline & Growth & & 3.43 & -3.99 & -16.13 & -1.25 & -4.49 \\
\hline
\end{tabular}

\section{8: Ranks of the Selected Commercial Banks Based on Financial Indicators:}

In order to summarize the classification of the banks based on their rank of activities and Profitability ratios, table (8) contains ranks of the positions for these banks. As it is shown 
in this table, rank of Bank Asia is the first position in average deposit per branch, average loans and advances per employees and branch and average net income per employees and branch, ROA and ROE. Further, it is in the last position among other banks in its branch employee's expansion, average deposit collection, and investment. Contrary to Bank Asia, Dutch Bangla (DBBL) got the last position in average deposit per branch, average loans and advances per branch, average net income per branch and average investment per branch. In addition, this bank is not ranked in the first position of any indicators. On the other hand, among the five banks to be ranked Prime Bank is in good position in all indicators. The profitability position of Brach bank is third and fourth rank based on its (ROA) and (ROE) despite of its first rank in employees, second rank in average loan and advances and third rank in branch expansion average deposit and investment. Investment position of Mercantile bank is to be ranked first and profitability position of per employee is third but ROA, ROE, average loan and advance and average income its ranked to be last.

\section{Conclusions and Recommendations}

During the period 2006-2010 all selected bank have proven the positive position of branch expansion and employment opportunities. All selected banks are increasing branch expansion and job creation. It proves the social commitment and profitability of PCBs because the social profitability of banking industry can be measured by branch expansion and employment generation (Lalarukh \& Hossain, 2008).

The results of the ranking of the selected banks based on the computed financial indicators revealed that, Prime Bank is the first position in average deposits. As regards average deposits, DBBL is ranked in the second position; Brack is ranked in third position, Mercantile Bank in fourth position, Bank Asia in fifth position. On the other hand, Prime Bank is the first position in average loan and advance and Brack Bank is second, Bank Asia is third, DBBL is fourth and Mercantile Bank is fifth respectively. In addition to average investment, Mercantile Bank is first ranked where Prime Bank is second, Brack Bank is third, DBBL is fourth and Bank Asia is fifth ranked respectively. As regards return on equity and return on assets, Bank Asia obtained the higher rank, DBBL in second and third position, Prime Bank in third and fourth position, Brack Bank in fourth and third position, Mercantile Bank in fifth position respectively. Based on ranking report, this study arrived that, banks with higher deposit, credits, investment does not always mean that it gain better profitable performance.

All the selected banks during the period 2006-10 deposit turnover, credit turnover and investment turnover are increasing. It indicates the commitment of the bank to the national economy and competitions. In the study, Bank Asia is fifth position in deposit collection, investment disbursement and third position in loan and advances but first position in ROA, ROE and second position in net income. It indicates the managerial efficiency of Bank Asia. On the other hand, Mercantile bank is fourth position in deposit collection but first position in investment it reveals that they invested huge money from internal sources. Moreover, Mercantile bank profitability position is very poor they ranked fifth in income, ROA and ROE. It shows the lack of managerial soundness and stability of the bank.

This study provide a clear picture of our banking sector that can be a source of help to bank managers to improve their financial performance and formulate policies that will promote effective financial system. The study also recommend measures that could be adopted by banks to ensure soundness in their operations and financial growth. Most of 
the selected banks are in financially sound position. So they can be said a healthy bank. Mercantile banks should pursue sound monetary and fiscal policies that will stimulate economic growth and development as banks perform well in a sound and stable economic environment. Also all banks should introduce different financial packages to increase deposit collection and expand their business to the mass people the country. Lastly, it can be concluded that our private commercial banks are playing a major role in our economic growth and stability and their financial health is sound.

Table 10: Ranks of selected banks

\begin{tabular}{|c|c|c|c|c|c|}
\hline $\begin{array}{c}\text { Banks/ } \\
\text { Indicators }\end{array}$ & $\begin{array}{l}\text { Bank } \\
\text { Asia }\end{array}$ & $\begin{array}{c}\text { Dutch Bangla } \\
\text { Bank }\end{array}$ & $\begin{array}{c}\text { Mercantile } \\
\text { Bank }\end{array}$ & $\begin{array}{l}\text { Prime } \\
\text { Bank }\end{array}$ & $\begin{array}{l}\text { Brack } \\
\text { Bank }\end{array}$ \\
\hline Branch & 5 & 2 & 4 & 1 & 3 \\
\hline Employees & 5 & 3 & 4 & 2 & 1 \\
\hline \multicolumn{6}{|l|}{ Deposit: } \\
\hline Average Deposit & 5 & 2 & 4 & 1 & 3 \\
\hline Per Employees & 2 & 3 & 4 & 1 & 5 \\
\hline Per Branches & 1 & 5 & 3 & 2 & 4 \\
\hline \multicolumn{6}{|l|}{ Loans \& Advances: } \\
\hline Average Loans \& Advances & 3 & 4 & 5 & 1 & 2 \\
\hline Per Employees & 1 & 4 & 3 & 2 & 5 \\
\hline Per Branches & 1 & 5 & 3 & 2 & 4 \\
\hline \multicolumn{6}{|l|}{ Investment: } \\
\hline Average Investment & 5 & 4 & 1 & 2 & 3 \\
\hline Per Employees & 3 & 4 & 1 & 2 & 5 \\
\hline Per Branches & 3 & 5 & 1 & 2 & 4 \\
\hline \multicolumn{6}{|l|}{ Income: } \\
\hline Average Income & 2 & 4 & 5 & 1 & 3 \\
\hline Per Employees & 1 & 3 & 3 & 2 & 4 \\
\hline Per Branches & 1 & 5 & 4 & 2 & 3 \\
\hline Return on Assets (ROA) & 1 & 4 & 5 & 2 & 3 \\
\hline Return on Equity (ROE) & 1 & 2 & 5 & 3 & 4 \\
\hline
\end{tabular}




\section{BIBLIOGRAPHY}

Annual Report. (2006-2010). Bank Asia Ltd, Dutch Bangla Bank Ltd, Mercantile Bank Ltd, Prime Bank Ltd and Brack Bank Ltd.

Almazari, A. F. (2012). Financial performance evaluation of some selected jordanian commercial banks. International Research Journal of Finance and Economics, 50-63

Chowdhury, F. (2010). Managerial effectiveness: a case study of bangladesh krishi bank. Bank Parikrama, 25, 82-102.

Chodhury, T.A, \& Kasfia, A. (2009). Performance evaluation of selected private commercial banks in Bangladesh. International Journal of Business and Management, 4(4), 87-97

Chowdhury, H. A., \& Islam, M. S. (2007). Interest rate sensitivity of loans and advances: a comparative study between nationalized commercial banks (ncbs) and specialized banks (sbs). ASA University Review, 1(1).

Chen. X. G , Skully. M, \& Brown, K. (2005). Banking efficiency in china: application of deato pre- and post-deregulation eras: 1993-2000. China Economic Review, 16, $229-245$

Chowdhury, A. (2002). Politics, society and financial sector reform in Bangladesh. International Journal of Social Economies, 29(12), 963 - 988.

Jahangir, N., Shill, S., \& Haque, M. A. J. (2007). Examination of profitability in the contextof bangladesh banking industry. ABAC Journal, 27, 2.

Lalarukh, F., \& Hossain, M. Z. (2008). A comparative study of the pcbss \& ncbs of bangladesh: a closer look into the NCBS. The Cost and Management, 15-22

Makkar, A., \& Singh, S. (2012). Evaluating the financial soundness of indian commercial banks: an application of bankometer. National Conference on Emerging Challenges for Sustainable Business, 118-132

Misir, M. A., \& Afsar, A. K. M. (2001). Comparative performance evaluation of pubali bank ltd and Islami bank Bangladesh ltd. Journal of institute of Bangladesh Studies, 24

Rahman, M. (1994). Trend of employee's productivity in commercial bank in Bangladesh. Journal of Rajshahi University Studies, 2, 85-94.

Rafiq, M. H., \& Farid. M. (2004). Productivity and performance of private commercial bank in Bangladesh. Journal of Rajshahi University Studies, 27, 137-156.

Rahman, M. H. (2001). Productivity performance evaluation of investment corporation of bangladesh. Journal of Rajshahi University Studies, 9

Siddique, S. H., \& Islam, A. F. M. M. (2001). Banking sector in bangladesh: its contribution and performance. Journal of Business Research, 3

Shakoor, S. A. (1989). Measurement of productivity in the commercial bank of Bangladesh bank parikrama,14, 34-61. 